\title{
PENILAIAN KUALITAS IMPLEMENTASI CORPORATE SOCIAL RESPONSIBILITY PADA PERUSAHAAN PERTAMBANGAN DI INDONESIA BERDASARKAN INDEKS GLOBAL REPORTING INITIATIF (GRI)
}

\section{Assessing The Quality Of Corporate Social Responsibility (CSR) Implementation In Mining Companies In Indonesia Using Index Global Reporting Initiative (GRI)}

\author{
Suharlina \\ Email: suharlinas@yahoo.com \\ STIE Muhammadiyah Mamuju
}

\begin{abstract}
ABSTRAK
Tujuan penelitian ini adalah untuk melihat implementasi Corporate Social Responsibiliy (CSR) perusahaan sesuai dengan indeks Global Reporting Inisiative (GRI) kemudian melihat apakah CSR yang dijalankan perusahaan sesuai dengan bidang usaha perusahaan dan kebutuhan masyarakat. Pendekatan penelitian yang digunakan adalah penelitian deskriptif. Objek dari penelitian ini adalah PT Antam, PT Bukit Asam, PT Medco Energy, dan PT Indo Tambangraya Megah. Keempat perusahaan ini dipilih karena sudah memenuhi kriteria pengambilan sample. Hasil penelitian menunjukkan bahwa PT Antam cukup memenuhi poin- poin dari indeks GRI sedangkan tiga perusahaan lainnya kurang memenuhi standar tersebut. Namun keempat perusahaan tersebut telah taat terhadap peraturan daerah tempat mereka beroperasi. Hal tersebut terlihat dari kegiatan CSR yang dijalankan perusahaan seperti pembangunan sarana dan prasarana, pemberian beasiswa dan pelatihan kepada karyawan dan masyarakat, pemberdayaan masyarakat seperti pemberian modal usaha mandiri, pembibitan sayur dan ikan, dan pelestarian lingkungan. PROPER yang diperoleh keempat perusahaan tersebut juga terbilang baik
\end{abstract}

\section{Kata Kunci: CSR, indeks GRI, BUMN dan Swasta}

\begin{abstract}
This research was to observe the implementation of Corporate Social Responsibility (CSR) using Global Reporting Initiative (GRI) index and to find out if the implementation is relevant with the company's business and the community's needs. This research applied a descriptive approach. The objects of the research were Antam Co. Ltd., Bukit Asam Co. Ltd., Medco Energy Co. Ltd., and Indo Tambangraya Co. Ltd. The four companies were selected because they met the sampling criteria. The results indicate that Antam Co. Ltd has met the standards of GRI index while the other three companies have not. However, the four companies in fact have also met to the local regulations applied in their mining sites. This can be seen in such CSR activities as the construction of facilities and infrastructures, the provision of grants and training for employees and communities, the community empowerment activities which include providing capital for independent businesses, vegetables seedling and fish breeding, as well as environment preservation. The PROPER acquired by the four companies was also fairly good.
\end{abstract}

Keyword: CSR, GRI index, state-owned enterprises and private 


\section{PENDAHULUAN}

Lingkungan bisnis sekarang ini mengharuskan perusahaan-perusahaan untuk tidak hanya memperhatikan faktor-faktor teknis dan finansial tetapi juga memperhatikan kesejahteraan masyarakat dan lingkungan sekitar (Mukti, 2012). Oleh karena itu, pemilik perusahaan juga harus memperhatikan reputasi perusahaannya, dan memperhatikan lingkungan sekitar, serta kesejahteraan masyarakat sekitar. Hal ini dilakukan karena seringkali masyarakat di sekitar perusahaan kehilangan mata pencaharian akibat dari aktivitas perusahaan. Perusahaan seringkali tidak sadar akan dampak dari kegiatannya yang secara umum dapat menimbulkan dampak positif atau negatif. Salah satu contoh dampak negatif adalah terjadinya berbagai peristiwa lingkungan akibat perusahaan yang tidak bertanggung jawab perusahaan sehingga meresahkan masyarakat sekitar. Apalagi di era modern ini banyak isu yang muncul tentang masalah lingkungan hidup dan keluhan masyarakat mengenai lingkungan yang tidak sehat serta kurangnya perhatian perusahaan kepada masyarakat yang tinggal di sekitar pabrik.

Dalam organisasi bisnis lokal dan global telah terjadi peningkatan pemikiran serta kesadaran akan konsep baru dan aplikasi dan relevansi dari CSR. CSR menurut Murdikanto (2014) adalah tentang bagaimana perusahaan mengelola proses bisnis untuk menghasilkan dampak positif secara keseluruhan pada masyarakat. Contoh bentuk tanggung jawab itu bermacam-macam, mulai dari melakukan kegiatan yang dapat meningkatkan kesejahteraan masyarakat dan perbaikan lingkungan, pemberian beasiswa untuk anak tidak mampu, pemberian dana untuk pemeliharaan fasilitas umum, sumbangan untuk desa/fasilitas masyarakat yang bersifat sosial dan berguna untuk masyarakat banyak, khususnya masyarakat yang berada di sekitar perusahaan tersebut. Pengimplementasian CSR dengan baik di perusahaan akan meningkatkan reputasi perusahaan dan dapat meningkatkan profitabilitas perusahaan yang secara tidak langsung akan meningkatkan kelangsungan hidup perusahaan. Pernyataan tersebut menjelaskan bahwa masalah CSR telah menyentuh persoalan material dalam perusahaan, joelh karena itu, dewan pengurus dan auditor internal perlu bertanggung jawab dan memastikan bahwa perusahaan mereka tidak akan mengalami kegagalan sesuai dengan yang diekspektasikan oleh shareholder dan manajemen perusahaan. Berdasarkan pernyataan ini sudah sangat jelas bahwa perusahaan harus memperhatikan kegiatan CSR karena keberhasilan CSR merupakan keberhasilan perusahaan juga. Semakin baik CSR yang dijalankan maka akan menjamin omset dan umur perusahaan tersebut. 
Praktik CSR di Indonesia ini didorong oleh perundang-undangan yakni UU Perseroan Terbatas No. 40 Tahun 2007 dan UU Penanaman Modal No. 25 Tahun 2007, yang mewajibkan setiap perseroan untuk melaksanakan CSR. Berdasarkan uraian tersebut, maka penelitian ini dilakukan untuk melihat bagaimana implementasi CSR perusahaan menggunakan indeks GRI, apakah program CSR yang dijalankan perushaan sesuai dengan bidang usaha perusahaan dan kebutuhan sosial masyarakat.

\section{Konsep CSR}

Perusahaan punya tanggung jawab terhadap lingkungan sosial dimana perusahaan berada. Inilah konsep dasar dari CSR (Corporate Social Responsibility). Adapun pelaksanaannya sesuai kemampuan perusahaan tersebut. Bentuk kegiatan dari tanggung jawab itu boleh bermacammacam, mulai dari melakukan kegiatan yang dapat meningkatkan kesejahteraan masyarakat dan perbaikan lingkungan, pemberian beasiswa untuk anak tidak mampu, pemberian dana untuk pemeliharaan fasilitas umum, sumbangan untuk desa/fasilitas masyarakat yang bersifat sosial dan berguna untuk masyarakat banyak, khususnya masyarakat yang berada di sekitar perusahaan tersebut berada, dan sebagaimana dikutip dalam (Laksana, 2012). Kesadaran CSR ini muncul sejak era dimana kesadaran akan sustainability perusahaan jangka panjang adalah lebih penting dari pada sekedar profitability.

\section{Definisi CSR}

Menurut Bowen (1953), CSR is an obligation of businessman to pursue those policies, to make those decision, or to follow those line of action which are desirable in term of the objectives and values of our society. Pengertian tersebut menjelaskan bahwa kewajiban perusahaan untuk merumuskan kebijakan, membuat keputusan, atau mengikuti garis tindakan yang diinginkan dalam hal tujuan dan nilai-nilai masyarakat.

Budimanta dalam Mardikanto (2014) mengartikan CSR sebagai komitmen perusahaan untuk membangun kualitas kehidupan yang lebih baik bersama dengan para pihak yang terkait, utamanya masyarakat disekeliling-nya dan lingkungan sosial dimana perusahaan tersebut berada, yang dilakukan terpadu dengan kegiatan usahanya secara berkelanjutan. Jadi menurut budimanta tersebut CSR merupakan kegiatan yang memperhatikan keinginan dari semua stakeholder yang dilakukan untuk keberlangsungan perusahaan itu sendiri. 


\section{Manfaat CSR}

Corporate Social Resonsibility merupakan komitmen perusahaan untuk mensejahterahkan masyarakat sekitar, dimana program ini memiliki manfaat yang besar bagi perusahaan jika dijalankan dengan baik. Perusahaan akan memperoleh banyak sekali manfaat selain akan lebih dihargai oleh masyarakat sekitar penjualan produkpun akan meningkat karna dijaman sekarang ini konsumen akan melihat reputasi perusahaan sebagai alasan untuk mengkonsumsi produk perusahaan tersebut. Adapun manfaat CSR menurut (Murdikanto, 2014)

\section{Penelitian Terdahulu}

Penelitian tentang CSR diantaranya pernah dilakukan oleh Jejen (2013). Penelitian dilakukan pada PT Sarihusada. Dalam penelitian tersebut, disimpulkan bahwa pelaksanaan CSR di PT Sarihusada menggunakan beberapa pola penerapan, seperti perusahaan terlibat langsung kepada masyarakat, bekerja sama dengan yayasan atau lembaga sosial yang begerak di bidang sosial, serta membentuk lembaga atau yayasan yang bergerak di bidang sosial. Maka menurut peraturan yang berlaku, kegiatan yang dilakukan Sarihusada belum sepenuhnya sesuai dengan peraturan yang ada. Pelaksanaan kegiatan CSR Sarihusada terhadap lingkungan sekitar dipandang belum berpengaruh besar terhadap lingkungan sekitar, dilihat dari pendapat masyarakat sekitar terhadap kegiatankegiatan sosial perusahaan hanya bersifat insidental.

\section{METODE PENELITIAN}

Pendekatan penelitian yang digunakan adalah metode analisis deskriptif, jenis data adalah data sekunder, data dikumpulkan dengan teknik mengambil laporan keberlanjutan perusahaan dari 2013-2014, dan annual report perusahaan dari 2012-2015. Dari data yang telah dikumpulkan, data dianalisis dengan teknik yang mengacu pada Analisa data kualitatif menurut Bogdan \& Biklen dalam Moleong (2007) adalah upaya yang dilakukan dengan jalan bekerja dengan data, mengorganisasi data, memilah- milahnya menjadi sesuatu yang dapat dikelola, mensintesiskannya, mencari dan menemukan pola, menemukan apa yang penting dan apa yang dipelajari, dan memutuskan apa yang dapat diceritakan kepada orang lain. Adapun aktivitas dalam analisis data antara lain adalah reduksi data, penyajian data dan kesimpulan dan verifikasi. 


\section{HASIL DAN PEMBASAHAN}

\section{Pelaksanaan CSR}

\section{Laporan Non Keuangan}

\section{PT ANTAM}

ANTAM telah melakukan penanaman 50 ribu pohon mangrove di area kritis Pulau Rambut di Kepulauan Seribu, ANTAM berkolaborasi dengan pemerintah daerah untuk mendukung peningkatan kualitas hidup masyarakat, salah satunya dengan pemberian bantuan pembangkit listrik tenaga surya sebanyak 5.500 unit PLTS-SHS kepada masyarakat, selain PLTS ANTAM juga memberikan bantuan fasilitas penerangan jalan umum pembangkit listrik tenaga surya(PJUPLTS). Perusahaan ANTAM bekerja sama dengan masyarakat sekitar melakukan Pengembangan sentra buah - buahan, penanaman buah-buahan sebanyak 40 ribu batang seperti buah manggis, alpukat, jambu, jamaika dan jambu Kristal di kecamatan nanggung, kabupaten bogor, jawa barat. Ini dilakukan oleh ANTAM untuk meningkatkan mata pencaharian masyarakat sekitar. Antam Melaksanakan kegiatan pendidikan dan pelatihan termasuk pula pemberian beasiswa kepada pelajar dan mahasiswa berprestasi serta beasiswa untuk para dosen untuk belajar ke luar negeri. Dalam bidang kesehatan, ANTAM fokus memberikan bantuan untuk pengadaan sarana dan prasarana kesehatan, seperti pembangunan gedung dan peralatan kesehatan puskesmas

\section{PT Bukit Asam}

Pada 2013, PTBA bekerja sama dengan Kementerian Perumahan Rakyat dan Pemerintah Daerah membantu 200 unit rumah layak huni yang diperuntukkan bagi masyarakat berpenghasilan rendah. Kegiatan ekonomi di daerah juga tumbuh oleh investasi yang dilakukan Perseroan di daerahdaerah operasi, termasuk untuk keperluan infrastruktur, perumahan karyawan, Rumah Sakit PTBA, dan fasilitas sosial dan umum bagi karyawan PTBA.

\section{MEDCO ENERGY}

Medco Energi telah merancang program bantuan bagi karyawan yang akan pensiun atau akan di PHK. Program-program ini (perencanaan pra- pensiun dan transisi ke kehidupan non- kerja, pelatihan ulang dan pesangon) bertujuan untuk mendukung dan membantu karyawan dalam mengelola akhir karir mereka dan melanjutkan kehidupan mereka setelah masa purna bakti di Medco Energi. 
Di wilayah sekitar pertambangan perusahaan membudidayakan tanaman karet organik dan bersama dengan 152 petani, serta membudidayakan perikanan lele dan gabus yang diberikan kepada 64 kelompok petani ikan.

\section{PT Indo Tambangraya Megah}

ITM telah mengembangkan enam fasilitas pembibitan, dengan total kapasitas produksi bibit sebanyak 852.390 bibit per tahun. Akan tetapi, untuk memenuhi kebutuhan bibit tanaman, ITM membimbing dan mendukung masyarakat lokal dalam hal pembibitan tanaman untuk penanaman kembali. Selanjutnya, ITM membeli bibit tanaman dari pihak-pihak yang tergabung dalam kelompok tani yang menyediakan bibit tersebut. Jumlah bibit yang dibeli rata- rata per tahunnya adalah 149,935. PT Kitadin Embalut (EMB), Pada tahun 2014 EMB terlibat dalam pembangunan dan perbaikan jalan dan jembatan di beberapa desa dampingan, serta pembangunan gedung sekolah di Desa Embalut. EMB juga mengembangkan kelompok peternakan sapi, pertanian terpadu, dan perikanan. Lokasi pertanian terpadu kelompok binaan EMB telah dijadikan lokasi studi banding oleh beberapa instansi perusahaan, pemerintahan, dan juga universitas.

\section{Pelaksanaan CSR berdasarkan Indeks GRI}

\section{a) PT ANTAM}

Berikut ini adalah grafik pelaksanaan CSR PT ANTAM berdasarkan indikator Indeks GRI:

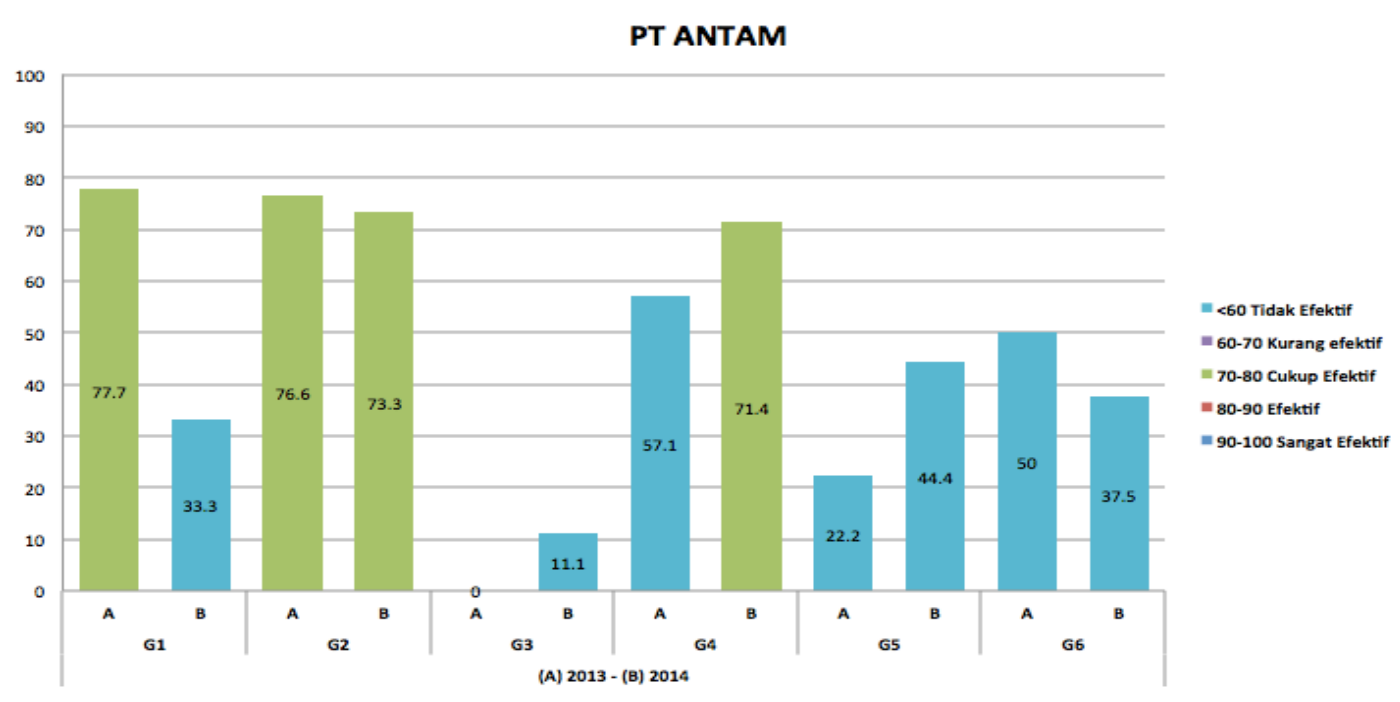

Grafik 1: Pelaksanaan CSR PT ANTAM 
Berdasarkan presentase yang ditunjukkan oleh grafik tersebut, pada tahun 2013, indikator G1 dan G2 dapat digolongkan cukup mencapai target, sementara indikator G3,G4,G5 dan G6 digolongkan tidak mencapai target. Untuk tahun 2014, indikator G2 dan G4 dapat digolongkan cukup mencapai target sementara indikator G1,G3,G5 dan G6 digolongkan tidak mencapai target dan jika dilihat dari Peraturan Daerah yang dikeluarkan oleh pemerintah daerah Jawa Barat perusahaan telah taat oleh peraturan- peraturan yang dikeluarkan pemerintah daerah, seperti pengelolaan lingkungan hidup dan itu didukung oleh Pencapaian PROPER yang dikeluarkan oleh Menteri Lingkungan Hidup yaitu PROPER biru.

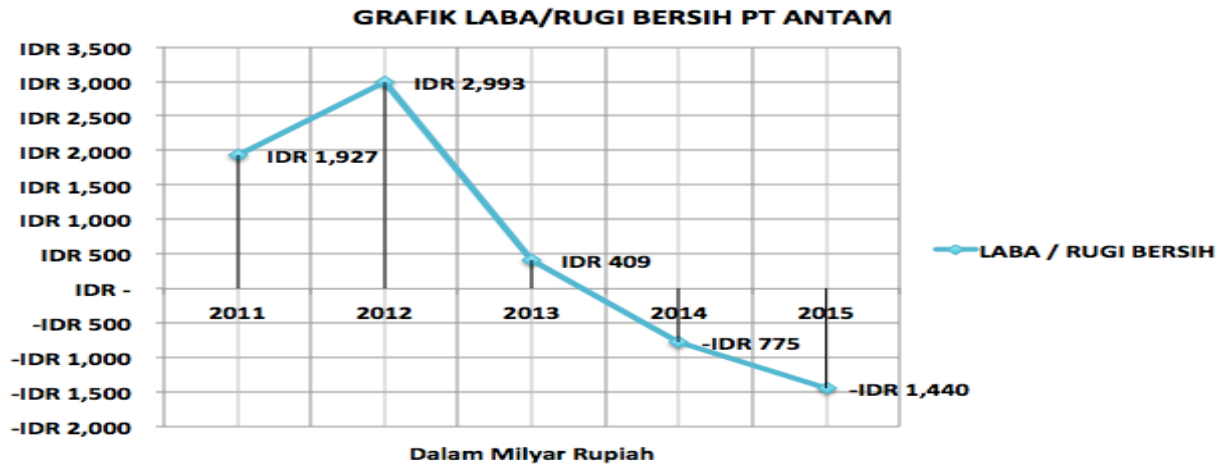

\section{Grafik 2: Laba/Rugi Bersih PT ANTAM dari tahun 2011-2015}

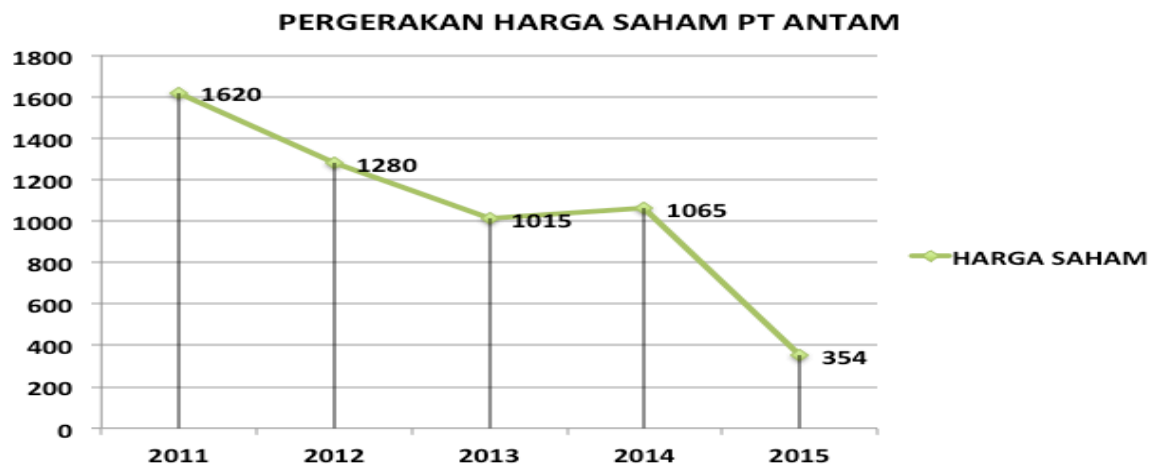

Grafik 3: Pergerakan Harga Saham PT ANTAM dari 2011-2015

Grafik diatas menunjukkan perubahan laba PT ANTAM dari tahun 2011-2015. Laba meningkat dari tahun 2011 ke tahun 2012 yaitu dari 1,927 menjadi 2,993. Namun, dari tahun 2012 hingga 2015 laba terus menurun hingga bahkan perusahaan mengalami kerugian. Pada tahun 2015 perusahaan mengalami kerugian sebesar - 1,440. Dapat dilihat pula pada grafik harga saham 
perusahaan, harga saham juga terus menerus mengalami penurunan hingga mencapi harga 354/lembar saham pada tahun 2015. Meskipun perusahaan mengalami kerugian hingga tahun 2015, pelaksanaan CSR perusahaan tetap berjalan dengan baik.

\section{PT Bukit Asam}

Berikut ini adalah grafik pelaksanaan CSR PT Bukit Asam berdasarkan indikator Indeks GRI:

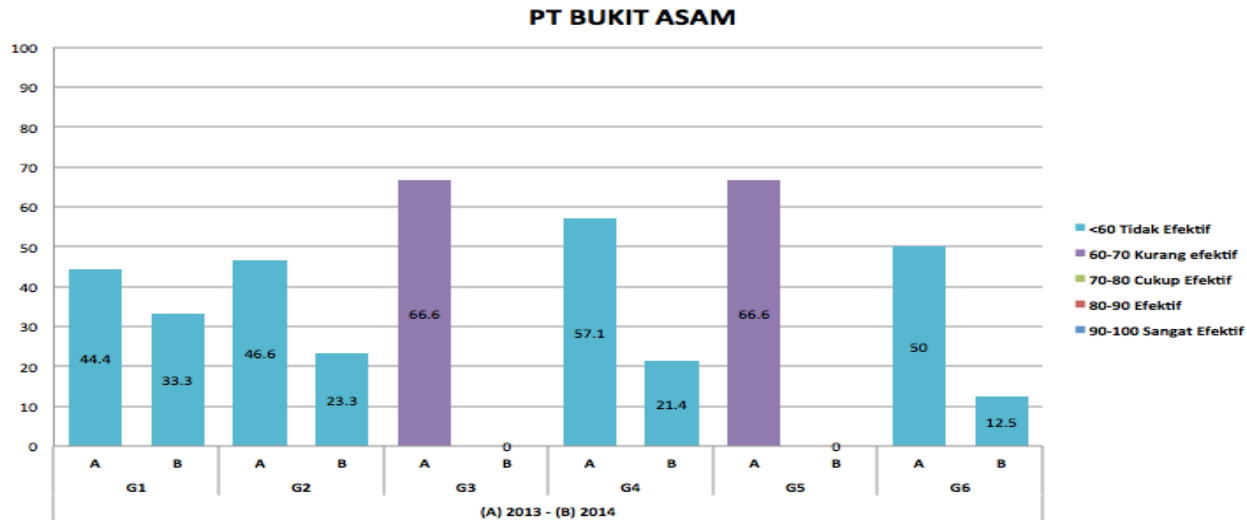

Grafik 4: Pelaksanaan CSR PT Bukit Asam

Berdasarkan presentase yang ditunjukkan oleh grafik tersebut, pada tahun 2013, indikator G3 dan G5 dapat digolongkan kurang mencapai target, sementara indikator G1,G2,G4 dan G6 digolongkan tidak mencapai target. Untuk tahun 2014, semua indikator digolongkan tidak mencapai target. Namun, jika dilihat dari Peraturan Daerah yang dikeluarkan pemerintah daerah lokasi perusahaan melakukan operasinya, perusahaan telah taat terhadap peraturan yang dikeluarkan seperti pengembangan wilayah sekitar tambang, pengembangan masyarakat dan memberi kesempatan kerja kepada masyarakat setempat serta meningkatkan kesejahteran masyarakat. Ini terdukung oleh Pencapaian PROPER yang dikeluarkan oleh Menteri Lingkungan Hidup yaitu PROPER emas.

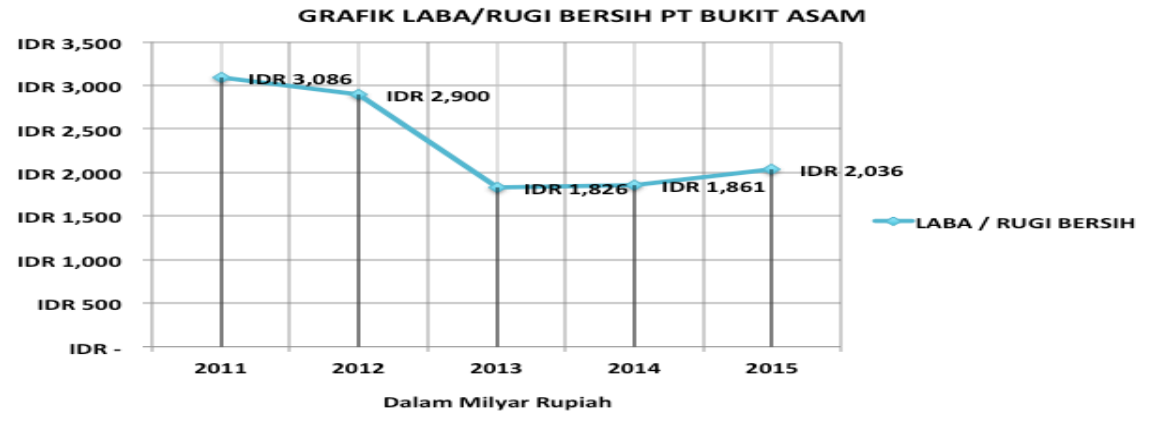

Grafik 5: Grafik Laba/Rugi Bersih PT Bukit Asam 


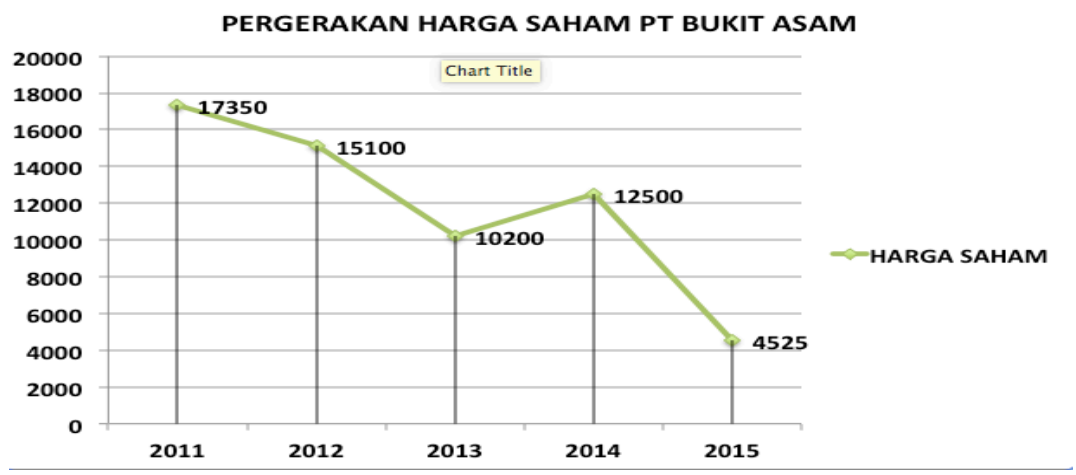

Grafik 6: Pergerakan Harga Saham PT Bukit Asam

Grafik diatas menunjukkan perubahan laba PT Bukit Asam dari tahun 2011-2015. Laba menurun dari tahun 2011 ke tahun 2014 yaitu dari 3,086 milyar rupiah menjadi 1,861 milyar rupiah. Namun, dari tahun 2014 ke tahun 2015 laba meningkat menjadi 2,036 milyar rupiah. Dapat dilihat pula pada grafik harga saham perusahaan, harga saham juga terus menerus mengalami penurunan hingga mencapi harga 4.525/lembar saham pada tahun 2015 meskipun pada tahun 2014 harga saham sempat naik di harga 12.500/lembar saham. Penurunan laba perusahaan sejalan dengan penurunan pelaksanaan CSR perusahaan.

\section{PT Medco Energi}

Berikut ini adalah grafik pelaksanaan CSR PT Medco Energi berdasarkan indikator Indeks GRI:

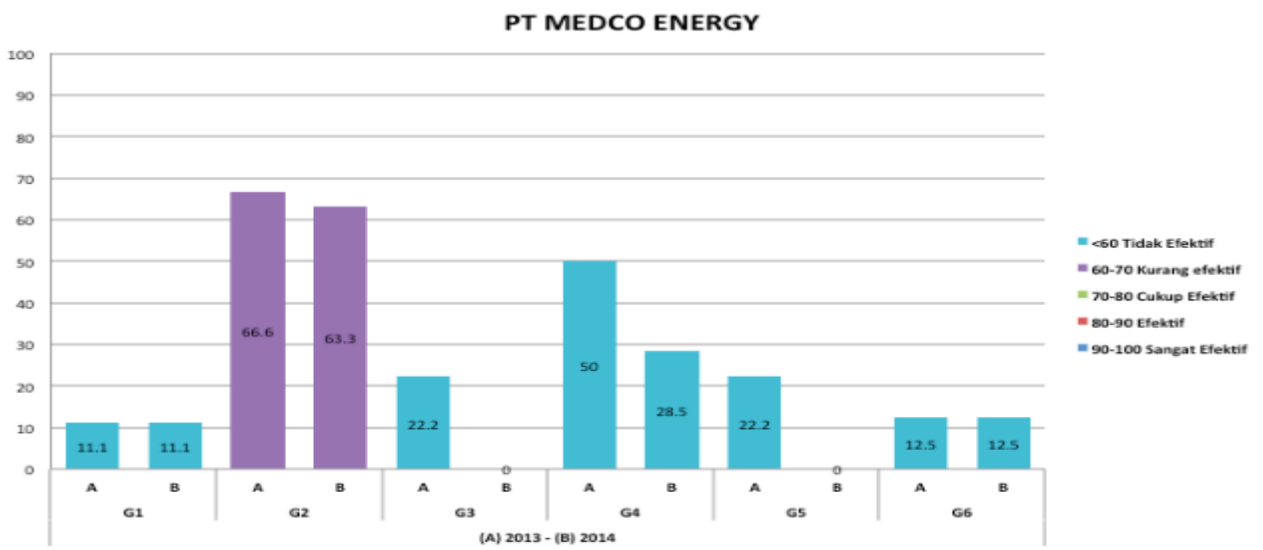

Grafik 7: Pelaksanaan CSR PT Medco Energi

Berdasarkan persentase yang ditunjukkan oleh grafik tersebut, pada tahun 2013, indikator G2 dapat digolongkan kurang mencapai target, sementara indikator G1,G3,G4,G5 dan G6 digolongkan tidak mencapai target. Untuk tahun 2014, indikator G2 dapat digolongkan kurang mencapai target, sementara indikator G1,G3,G4,G5 dan G6 digolongkan tidak mencapai target. 
Meskipun perusahaan banyak tidak memenuhi poin-poin yang ada pada indeks GRI tetapi jika dilihat berdasarkan Peraturan daerah yang dikeluarkan pemerintah daerah tempat medco melakukan operasinya, perusahaan telah taat pada Peraturan daerah. ini didukung oleh Pencapaian PROPER yang dikeluarkan oleh Menteri Lingkungan Hidup yaitu PROPER emas.

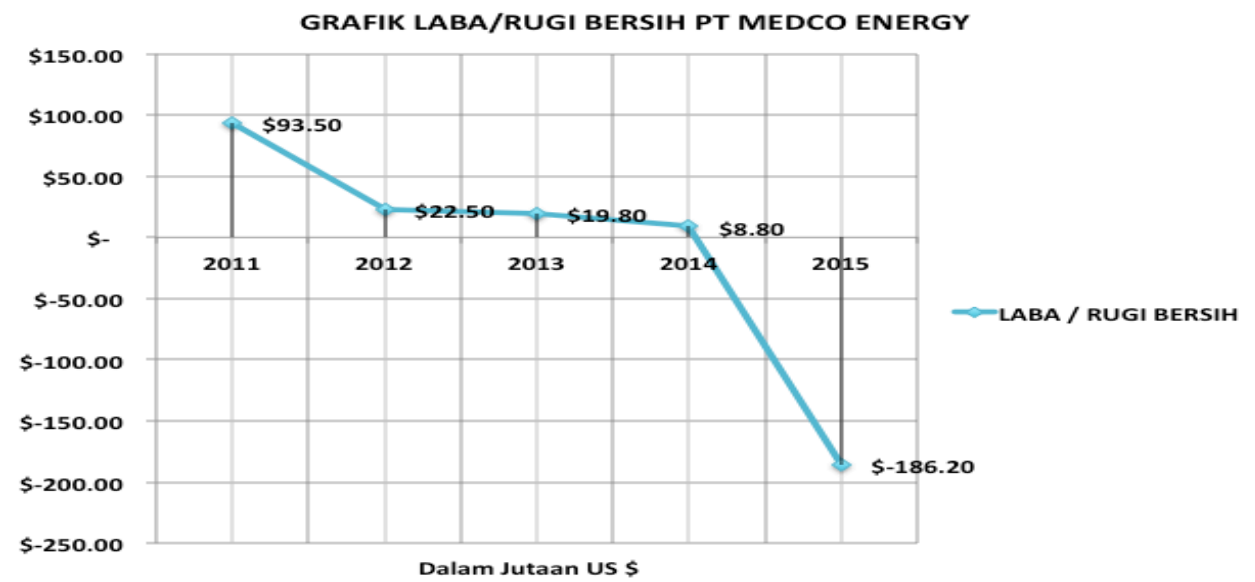

Grafik 8: Grafik Laba/Rugi Bersih PT Medco Energi

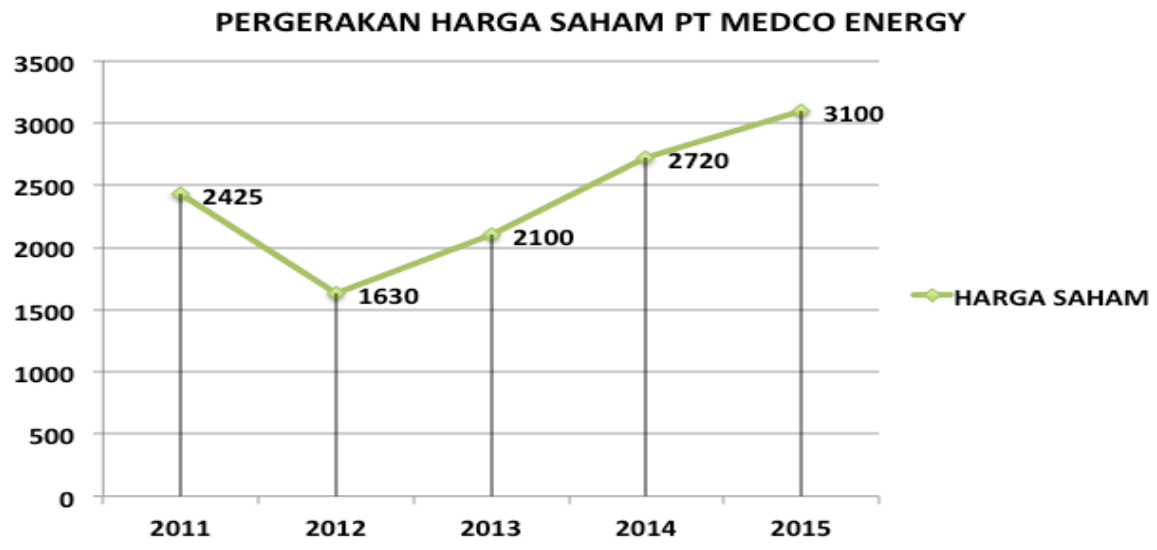

\section{Grafik 9: Grafik Pergerakan Harga Saham PT Medco Energi}

Grafik diatas menunjukkan perubahan laba PT Medco Energy dari tahun 2011-2015. Laba terus mengalami penurunan dari tahun ketahun hingga pada tahun 2015 perusahaan mengalami kerugian sebesar 186 juta dollar. Namun, jika dilihat pada grafik harga saham perusahaan, meskipun dari tahun 2011-2012 sempat mengalami penurunan, namun pada tahun selanjutnya sampai pada tahun 2015 harga saham terus menerus mengalami peningkatan hingga pada tahun 2015 harga saham mencapai 3100/lembar saham. Penurunan laba perusahaan sejalan dengan penurunan pelaksanaan CSR perusahaan . 


\section{PT Indo Tambangraya Megah}

Berikut ini adalah grafik pelaksanaan CSR PT Indo Tambangraya Megah berdasarkan indikator Indeks GRI:

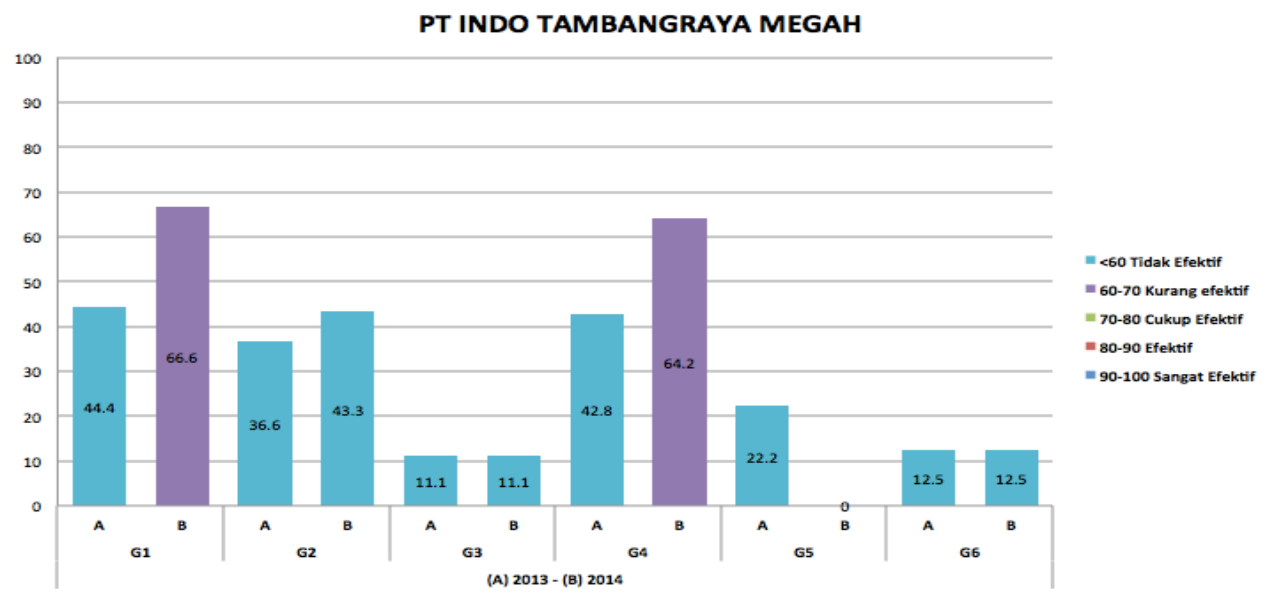

\section{Grafik 10: Pelaksanaan CSR PT Indo Tambangraya Megah}

Berdasarkan presentase yang ditunjukkan oleh grafik tersebut, pada tahun 2013, semua indikator digolongkan tidak mencapai target. Untuk tahun 2014, indikator G1 dan G4 dapat digolongkan cukup mencapai target, sementara indikator G2,G3,G5 dan G6 digolongkan tidak mencapai target. Meskipun beberapa point - point indeks GRI yang tidak terpenuhi, namun perusahaan telah taat terhadap Peraturan Daerah yang telah ditetapkan seperti pengelolaan lingkungan hidup, dan memperhatikan sarana dan prasarana daerah sekitar wilayah tambang dan ini didukung oleh Pencapaian PROPER yang dikeluarkan oleh Menteri Lingkungan Hidup yaitu PROPER Hijau.

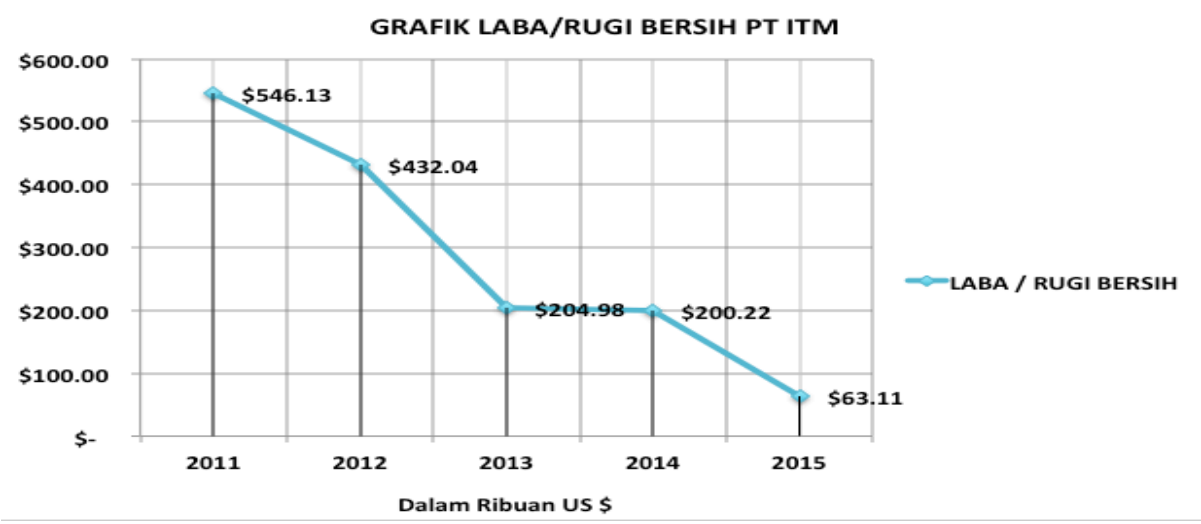

Grafik 11: Laba/rugi bersih PT Indo Tambangraya Megah 


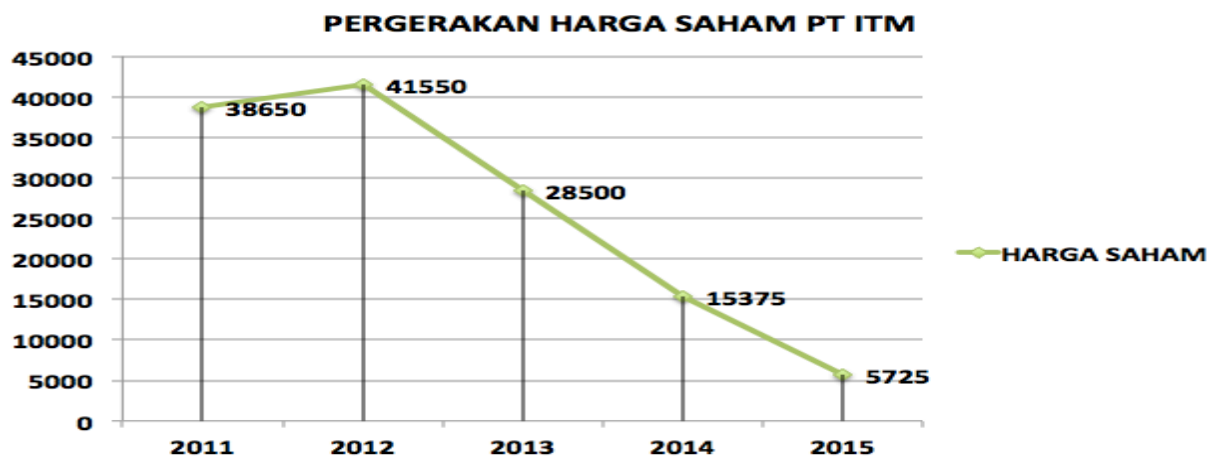

\section{Grafik 12: Pergerakan Harga Saham PT Indo Tambangraya Megah}

Grafik diatas menunjukkan perubahan laba PT Indo Tambangraya Megah dari tahun 20112015. Laba perusahaan terus mengalami penurunan, dari tahun 2011 jumlah laba perusahaan yaitu 546 ribu dollar hingga pada tahun 2015, laba perusahaan 63 ribu dollar, Dapat dilihat pula pada grafik harga saham perusahaan, harga saham juga terus menerus mengalami penurunan dari tahun ketahun hingga mencapi harga 5725/lembar saham pada tahun 2015. Meskipun perusahaan mengalami penurunan laba hingga tahun 2015, namun pelaksanaan CSR perusahaan mengalami peningkatan. Dilihat dari program-program CSR yang dijalankan, tidak begitu banyak perbedaan antara perusahaan BUMN dan perusahaan swasta. Pada dasarnya, program-program CSR yang dijalankan perusahaan-perusahaan tersebut mencakup kegiatan dalam bidang pendidikan, kesehatan, pemberdayaan masyarakat, serta pemberdayaan lingkungan.

\section{KESIMPULAN}

a) Implementasi CSR di 4 perusahaan

- PT ANTAM, implementasi CSR perusahaan cukup memenuhi beberapa poin dari indeks GRI. Ini dilihat dari beberapa indikator cukup mencapai target dan perusahaan juga telah mentaati peraturan daerah tempat perusahaan melakukan operasinya. Perusahaan telah mendapatkan PROPER biru yang dikeluarkan oleh menteri lingkungan hidup.

- PT Bukit Asam, implementasi CSR di perusahaan kurang memenuhi poin-poin dari indeks GRI, tetapi perusahaan telah taat terhadap peraturan daerah tempat perusahaan melakukan kegiatan pertambangan. Perusahaan juga memperoleh PROPER emas dari menteri lingkungan hidup . 
- PT Medco Energy, implementasi CSR diperusahaan tidak memenuhi poin-poin dari indeks GRI, tetapi perusahaan telah taat terhadap Peraturan Daerah dimana perusahaaan melakukan kegiatan tambang. Perusahan memperoleh PROPER emas dari menteri lingkungan hidup.

- PT Indo Tambangraya Megah, implementasi CSR diperusahaan kurang memenuhi poin-poin dari indeks GRI, tetapi perusahaan telah taat terhadap peraturan daerah tempat perusahaan melakukan tambang dan ini didukung oleh PROPER yang diterima dari menteri lingkungan hidup yaitu PROPER Hijau.

b) Program CSR perusahaan telah sesuai dengan bidang usaha perusahaan dan cukup memenuhi kebutuhan sosial masyarakat sekitar

- PT ANTAM, perusahaan telah melakukan penanaman pohon, membantu masyarakat dalam pengembangan sentra buah - buahan, mendukung peningkatan kualitas hidup masyarakat dengan membangun sarana dan prasarana di daerah sekitar wilayah tambang.

- PT Bukit Asam, perusahaan membuat hutan kota dan hutan pendidikan didaerah bekas tambang, memberikan pelatihan dan beasiswa kepada masyarakat dan karyawan, membangun rumah layak huni buat masyarakat berpenghasilan rendah.

- PT Medco Energy, perusahaan membudidayakan karet organik dan budidaya ikan lele dan gabus bersama masyarakat, memberikan pelatihan terhadap karyawan dan beasiswa kepada masyarakat,

- PT Indo Tambangraya Megah, perusahaan melakukan pengelolaan lingkungan hidup, memberikan beasiswa, dan bantuan sarana dan prasarana untuk masyarakat sekitar wilayah tambang.

\section{Saran}

1. Sebaiknya perusahaan lebih memperhatikan pelaksanakan CSR sesuai dengan indeks GRI. Rata-rata perusahaan lebih berfokus pada kegiatan CSR yang berkaitan dengan lingkungan dan kurang memperhatikan hal terkait hak asasi manusia dan produknya.

2. Meskipun perusahaan tidak diwajibkan untuk melaporkan data keuangan dana CSR, namun sebaiknya perusahaan tetap mengungkapkan jumlah dana CSR yang dikeluarkan perusahaan.

3. Bagi peneliti selanjutkan sebaiknya menggunakan sampel perusahaan yang lebih banyak agar bisa mewakili populasi perusahaan. Selain itu peneliti lebih baik melakukan wawancara 
terhadap pihak perusahaan dan masyarakat sekitar perusahaan untuk mendapatkan data yang lebih baik

\section{DAFTAR PUSTAKA}

Aneka Tambang. Laporan Pertanggungjawaban Perusahaan. 2013. Diakses pada 07 Juli 2015 di Http://www.antam.com

Aneka Tambang. Laporan Pertanggungjawaban Perusahaan. 2014. Diakses pada 07 Juli 2015 di Http://www.antam.com

Aneka Tambang. Laporan Tahunan Perusahaan. (2011-2015). Diakses pada 09 Oktober 2016 di Http://www.antam.com

Bowen, Horward R. 1953. Social Responsibilities of the Businessman.New York. Harper and Brothers

Bukit Asam. Laporan Pertanggungjawaban Perusahaan. 2013. Diakses pada 07 Juli 2015 di Http://ptba.co.id

Bukit Asam. Laporan Pertanggungjawaban Perusahaan. 2014. Diakses pada 07 Juli 2015 di Http://ptba.co.id

Bukit Asam. Laporan Tahunan Perusahaan. (2011-2016)5. Diakses pada 09 Oktober 2016 di Http://ptba.co.id

GRI. Empowering Sustainable Decisions. Diakses pada 23 Agustus 2016

https:/www.globalreporting.org/information/sustainability-reporting/Pages/default.aspx

Laksana,Wijaya. 2012. Implementasi corporate social responsibility dalam membentuk reputasi perusahaan.

Mardikanto,totok.2014. Corporate Social Responbility (Tanggung Jawab Sosial Korporasi). Bandung; Alphabeta

Medco Energy. Laporan Pertanggungjawaban Perusahaan. 2013. Diakses pada 20 September 2015 di Http://www.medcoenergi.com

Medco Energy. Laporan Pertanggungjawaban Perusahaan. 2014. Diakses pada 20 September 2015 di Http://www.medcoenergi.com

Medco Energy. Laporan Tahunan Perusahaan. 2011. Diakses pada 09 Oktober 2016 di Http://www.medcoenergi.com

Medco Energy. Laporan Tahunan Perusahaan. 2011-2015. Diakses pada 09 Oktober 2016 di Http://www.medcoenergi.com 
Mukti Arief Faladia, 2012. Implementasi Strategi CSR (corporate Social Responsibility) pada PT. Petrokimia Gresik.

Moleong, Lexy J. Metodologi Penelitian Kualitatif. Bandung: Remaja Rosda karya, 2007.

Susanto, daniel. 2007. Peranan Audit Internal Terhadap Kepatuhan Manajemen Perusahaan Di PT Otto Parmaceutical Industries Ltd. Skripsi. Fakultas ekonomi universitas widyatama dari 